\title{
Risk estimation of large complex bridge construction based on factor analysis
}

\author{
Li Qingfu ${ }^{1}$, Lei Jia ${ }^{2}$, Zhang Hua ${ }^{1, *}$ \\ ${ }^{1}$ ZhengzhouUniversity School of water Conservancy Science and Engineering, HeNan Zhengzhou 450000 \\ ${ }^{2}$ HeNan Provincial Communications Planning, Survey \& Design Institute CO., LTD. HeNan Zhengzhou 450000
}

\begin{abstract}
Based on the basic theory of factor analysis, this paper analyzes the risk factors of large-scale bridge construction through questionnaire surveys and expert scoring methods, summarizes the basic data of factors affecting bridge construction, and then analyzes the possible application of factor analysis in bridge construction risk analysis Sex. Based on the statistical processing of the data by the IBM SPSS Statistics V21.0 software, the applicability of the method was verified through factor extraction, factor rotation, consistency analysis and construction validity, and pointed out that six types of main factors affecting the safety of bridge construction Factors, calculate the importance index and correlation of each risk factor, and sort them by size, so as to estimate the risk consequences of bridge construction in a targeted manner, and invest reasonable efforts to control according to the size and importance of the risk, so that the risk control process is more Reasonable and targeted.
\end{abstract}

\section{Introduction}

The construction of large bridges often has to face the complex social environment and natural conditions. In addition, it needs a long construction period, complex structural system, relatively high construction technology, and complex external relations, which makes a series of uncertain factors in the process of bridge construction, thus causing construction safety risks ${ }^{[1]}$. In recent years, experts at home and abroad have begun to study the risk of bridge construction. Zhao $\mathrm{SJ}^{[2]}$ made statistics on bridge collapse accidents in recent 20 years in China, and the results show that the collapse proportion of bridges in construction period accounts for one third of 151 samples. Cho ${ }^{[3]}$ put forward quantitative risk assessment method for suspension bridge construction stage based on finite element model; Azis $\mathrm{S}^{[4]}$ used risk decomposition structure (RBS) method to classify and manage risks to determine the construction method of steel frame bridge; Haslam $\mathrm{r}$ a ${ }^{[5]}$ and others studied 100 construction accidents and found that construction personnel, construction equipment and management personnel played an important role in construction accidents; Ning $\mathrm{x}^{[6]}$ established the safety risk assessment function according to the probability of accidents and the linear attenuation law, and verified the effectiveness of the model through an example. In the aspect of bridge construction risk identification: de $\mathrm{L}^{[7]}$ introduced the related concepts and evaluation methods of construction management risk in the process of bridge construction, and according to the characteristics of construction management risk, proposed how to reduce the management risk scheme. Based on the reliability theory, Stewart ${ }^{[8]}$ analyzes the bridge construction risk from two aspects, one is risk decision analysis, the other is life cycle cost analysis. Sexsmith ${ }^{[9]}$ analyzed the safety of temporary facilities during bridge construction, and studied the influence of dead load and live load on the safety performance of scaffold from the perspective of safety reserve. Liu QC ${ }^{[10]}$ combined ant colony algorithm with BP neural network to establish a model for Optimizing BP neural network by ant colony algorithm to study the risk of bridge construction period. Ouyang Xin ${ }^{[11]}$ proposed a comprehensive risk identification method for bridge construction based on accident summary, structural analysis, on-site investigation and expert investigation; Zhang XD ${ }^{[12]}$ and others identified possible risk sources in bridge construction process through analytic hierarchy process; Song $\mathrm{CZ}^{[13]}$ proposed risk identification in bridge construction process based on fuzzy judgment analysis and combined with finite element analysis. In terms of bridge construction risk assessment methods and systems: Lu XX ${ }^{[14]}$ and others established a bridge risk assessment model based on Kent index method; Lou Feng ${ }^{[15]}$ and others proposed a quantifiable risk assessment method for highway bridge construction safety based on Monte Carlo sampling technology; $\mathrm{Xu} \mathrm{ZS}^{[16]}$ and others put forward a risk assessment method for PERT network plan, which adopts logical relationship determination and activity duration uncertainty. In the aspect of bridge construction risk management and control: Huang Xing ${ }^{[17]}$ et al. Defined the safety control for people, objects, environment and management in the process of bridge construction; Ruan Xin ${ }^{[18]}$ proposed a dynamic management method system of construction process based on construction scene.

* Correspondence:zhh@gs.zzu.edu.cn 
At present, the research results of safety risk of large bridges are limited and the evaluation criteria are not unified. The evaluation methods are: AHP, fuzzy comprehensive evaluation, Monte Carlo simulation, grey entropy correlation and BP neural network. These methods are based on the risk assessment of all risk factors, and lack of effective analysis and classification of bridge construction risk factors. Because of the large-scale bridge construction period of many risk factors, and different factors on the bridge construction impact are different, this paper attempts to use factor analysis method to large bridge construction risk factors screening, through the means of reducing the order of high-dimensional matrix into a low-dimensional matrix, calculate the importance index and correlation of each risk factor, and sort by size. The selection of key factors affecting the construction of large bridges is used to evaluate quantitatively, and the interference of no key indexes can be eliminated, which can improve the accuracy of bridge construction risk assessment, and reasonably invest energy to control according to the risk size and importance, so as to ensure the construction quality.

\section{Determination of major risk factors}

\subsection{Principles for determining risk factors for large and complex bridge construction}

In the process of large-scale bridge construction, due to many uncertain factors, any structural component may have construction risk. In order to avoid risk accidents in the construction process of bridge and ensure the safety of bridge structure construction, the disaster causing factors survey should be carried out in the whole construction process, which should be comprehensive, scientific, comparable and testability.

(1) Comprehensive

The construction period of large bridge is long, the construction process is complex, and the external environment of construction is changeable. The potential safety hazard exists in any step or stage of the whole construction process. Therefore, comprehensive risk investigation and expert experience method are adopted to comprehensively identify various risk factors, so as to screen out risk factors without omission.

(2) Scientific

Delphi method is also known as the expert scoring method, which mainly collects the opinions of experts in the industry, makes repeated feedback and correction, and finally forms stable opinions. Select about 20 experts and ask each expert not to contact with each other. The experts grade the investigated problems, and then sort out the scoring of each expert. When the results are inconsistent, feed-back to score again, and repeat the operation until a consensus is reached. Using expert scoring method can ensure the scientific results.

(3) Comparable

The comparability of risk factors identification for large complex bridge construction is an important criterion for determining risk factors. There are some differences in the results of different risk factors identification methods. In this paper, the combination of questionnaire survey method and Delphi method can more accurately identify the risk factors in the construction process of large bridges. Compared with other single type identification methods, this method is more comparable and can comprehensively determine risk factors.

(4) Testability

The measurability of risk factors means that through the numerical quantification method, the size of the risk degree is expressed with specific numbers, which is more concise and easy to distinguish, so as to improve the accuracy of risk identification process.

\subsection{Method for determining risk factors of large complex bridge construction}

From the natural environment (such as the hydrological conditions, geological conditions, climate) faced by the project, the adopted construction organization design scheme, the management level and technical level of the construction team, the social environment and human environment (the support of the local government, the public support for the project, local customs), the service coordination degree of the owner and the allocation of the subcontractor In this paper, a comprehensive survey table of risk factors in the whole process of bridge construction is established. However, in the actual bridge construction process, not every risk factor will have an impact on the safety of large-scale bridge construction. The risk factors with weak disaster causing capacity will not evolve into risk events. Some risk factors represent the same risk event Therefore, it is necessary to identify and analyze many risk factors in the construction process and screen out the key risk factors, which are often called disaster causing factors [19].

Through the Delphi method, experts evaluate and screen the risk factors according to the actual engineering situation, and quantify the risk degree of each factor into a specific value, and directly screen out the risk factors affecting the construction of large bridges. Through the risk factor questionnaire of experts ${ }^{[20]}$, the safety risk factors of large and complex bridge construction are obtained (As shown in Table 1). In the specific project, the coefficient can be increased or decreased according to the actual engineering situation.

Table1. Risk factors for large bridge construction

\begin{tabular}{cccc}
\hline Serial number & Risk factor & $\begin{array}{c}\text { Serial } \\
\text { number }\end{array}$ & Risk factor \\
\hline V1 & Rationality factors of project & V25 & $\begin{array}{c}\text { Design and construction } \\
\text { relationship factors }\end{array}$ \\
V2 & plan & V26 & New bridge design factors \\
V3 & Water and electricity supply & V27 & Accuracy factors of design data \\
\hline
\end{tabular}




\begin{tabular}{|c|c|c|c|}
\hline V4 & $\begin{array}{l}\text { Application of new technology } \\
\text { and new material }\end{array}$ & V28 & $\begin{array}{l}\text { Effectiveness factors of design } \\
\text { content }\end{array}$ \\
\hline & & & $\begin{array}{r}\text { Continued } \\
\text { Table 1 } \\
\end{array}$ \\
\hline Serial number & Risk factor & $\begin{array}{l}\text { Serial } \\
\text { number }\end{array}$ & Risk factor \\
\hline V5 & Climatic factors & V29 & $\begin{array}{l}\text { Delay factors of design change } \\
\text { and approval }\end{array}$ \\
\hline V6 & Construction technology factors & V30 & $\begin{array}{c}\text { Drowning, electric shock and } \\
\text { heatstroke }\end{array}$ \\
\hline V7 & People fall factors & V31 & Inadequate investigation factors \\
\hline V8 & Regulatory management factors & V32 & $\begin{array}{c}\text { Regulatory and approval process } \\
\text { factors }\end{array}$ \\
\hline V9 & $\begin{array}{l}\text { Rationality of construction } \\
\text { scheme }\end{array}$ & V33 & Normative sustainability factors \\
\hline V10 & $\begin{array}{l}\text { Personnel protection awareness } \\
\text { factors }\end{array}$ & V34 & Personnel safety factors \\
\hline V11 & $\begin{array}{l}\text { Mechanical collision and } \\
\text { impact injury }\end{array}$ & V35 & Personnel change factors \\
\hline V12 & Social and cultural factors & V36 & $\begin{array}{c}\text { Coordination factors between } \\
\text { construction unit and supervision } \\
\text { project }\end{array}$ \\
\hline V13 & Adverse environmental factors & V37 & $\begin{array}{l}\text { Quality factors of management } \\
\text { personnel }\end{array}$ \\
\hline V14 & Geological factors & V38 & $\begin{array}{l}\text { Quality factors of technical } \\
\text { personnel }\end{array}$ \\
\hline V15 & $\begin{array}{l}\text { Installation and commissioning } \\
\text { factors of construction } \\
\text { equipment }\end{array}$ & V39 & $\begin{array}{l}\text { Quality factors of construction } \\
\text { personnel }\end{array}$ \\
\hline V16 & $\begin{array}{l}\text { Construction machinery and } \\
\text { power factor }\end{array}$ & V40 & Falling objects \\
\hline V17 & Equipment capacity factor & V41 & Toxic gas leakage factors \\
\hline V18 & $\begin{array}{l}\text { Supporting or qualified factors } \\
\text { of construction equipment }\end{array}$ & V42 & $\begin{array}{l}\text { Complexity of geological } \\
\text { conditions }\end{array}$ \\
\hline V19 & Team operation level factors & V43 & Perfection of contract \\
\hline V20 & $\begin{array}{l}\text { Improper maintenance and } \\
\text { mechanical maintenance factors }\end{array}$ & V44 & $\begin{array}{l}\text { On site organization and } \\
\text { management factors }\end{array}$ \\
\hline V21 & Quality factors of raw materials & V45 & Personnel operation factors \\
\hline V22 & $\begin{array}{l}\text { Safety training education } \\
\text { factors }\end{array}$ & V46 & $\begin{array}{l}\text { Influence of foundation } \\
\text { settlement factors on structures }\end{array}$ \\
\hline V23 & Safety measures & V47 & Traffic accident factors \\
\hline V24 & $\begin{array}{l}\text { Design and construction factors } \\
\text { of temporary facilities }\end{array}$ & V48 & Emergency measures \\
\hline
\end{tabular}

\section{Bridge construction risk assessment model based on factor analysis}

\subsection{Principle of factor analysis}

The factor analysis method transforms multiple complex variables into fewer uncorrelated factors by means of dimensionality reduction. Set up a variable $x_{1}, x_{2}, \ldots, x_{p}$, the original variable is first standardized, the average value of the variable is changed to 0 , the standard deviation is changed to 1 , and then the original variable is represented $^{[21]}, k<p$, That is as follows:

$$
\left\{\begin{array}{c}
x_{1}=a_{11} F_{1}+a_{12} F_{2}+\ldots+a_{1 k} F_{k}+\varepsilon_{1} \\
x_{2}=a_{21} F_{1}+a_{22} F_{2}+\ldots+a_{2 k} F_{k}+\varepsilon_{2} \\
\ldots \\
x_{p}=a_{p 1} F_{1}+a_{p 2} F_{2}+\ldots+a_{p k} F_{k}+\varepsilon_{p}
\end{array}\right.
$$


Among them, $a_{i j}$ is the factor load, reflecting the degree of correlation between $X_{i}$ and $F_{j} . \varepsilon$ is a special factor, used to indicate the part that cannot be covered by the common factors.

$h_{\mathrm{i}}^{2}$ is the degree of commonality of variable $X_{i}, S_{j}$ is the factor factor variance contribution index, and the expression is as follows:

$$
\begin{gathered}
h_{i}^{2}=\sum_{j=1}^{k} a_{i j}^{2} \\
s_{j}=\sum_{j=1}^{p} a_{i j}^{2}
\end{gathered}
$$

\subsection{Factor extraction and factor loading matrix solution}

The solution of factor load matrix is the focus of factor analysis, generally use principal component analysis to solve. The principal component analysis is a method of transforming a set of related variables $x_{i}$ into another set of unrelated variables $y_{i}$ by coordinate transformation, which is expressed as follows:

$$
\left\{\begin{array}{c}
y_{1}=u_{11} x_{1}+u_{12} x_{2}+\ldots+u_{1 k} x_{k} \\
y_{2}=u_{21} x_{1}+u_{22} x_{2}+\ldots+u_{2 k} x_{k} \\
\ldots \\
y_{p}=u_{p 1} x_{1}+u_{p 2} x_{2}+\ldots+u_{p k} x_{k}
\end{array}\right.
$$

among them, $u_{1 k}^{2}+u_{2 k}^{2}+u_{3 k}^{2}+\ldots+u_{p k}^{2}=1$

$(k=1,2,3, \ldots, p)$

(1) Data standardization processing

$$
x_{i j}^{*}=\frac{x_{i j}-x_{j}}{s_{j}}
$$

$$
x_{j}=\frac{\sum_{i=1}^{n} x_{i j}}{n} \quad, \quad s_{j}=\frac{\sum_{j=1}^{n}\left(x_{i j}-x_{j}\right)^{2}}{n-1},
$$

$i=1,2,3, \ldots, n$ is the number of sample points, $j=1,2,3, \ldots, p$ is the number of original variables in the sample.

$$
\left[x_{i j}^{*}\right]_{n \times p}=\left[x_{i j}\right]_{n \times p}
$$

(2) Calculate the covariance matrix $R$ of the normalized matrix $\left[x_{i j}\right]_{n \times p}$.

(3)Find the first $m$ eigenvalues of $R$, $\lambda_{1} \geq \lambda_{2} \geq \ldots \geq \lambda_{m}$, and the corresponding eigenvectors $u_{1}, u_{2}, u_{3}, \ldots, u_{m}$, which are orthogonal.

Find the factor load matrix of $m$ variable:

$$
A=\left[\begin{array}{cccc}
a_{11} & a_{12} & \ldots & a_{1 m} \\
a_{21} & a_{22} & \ldots & a_{2 m} \\
& & \ldots & \\
a_{p 1} & a_{p 2} & \ldots & a_{p m}
\end{array}\right]=\left[\begin{array}{llll}
u_{11} \sqrt{\lambda_{1}} & u_{21} \sqrt{\lambda_{2}} & \ldots & u_{m 1} \sqrt{\lambda_{m}} \\
u_{12} \sqrt{\lambda_{1}} & u_{22} \sqrt{\lambda_{2}} & \ldots & u_{m 2} \sqrt{\lambda_{m}} \\
& & \ldots & \\
u_{1 p} \sqrt{\lambda_{1}} & u_{2 p} \sqrt{\lambda_{2}} & \ldots & u_{m p} \sqrt{\lambda_{m}}
\end{array}\right]
$$

\subsection{Application examples}

The factor analysis method is used to calculate the importance index of the construction risk factors of a large bridge in Zhongkai Motorway, and the data is processed with the help of IBM SPSS Statistics V21.0 software, and the bridge construction risk factors are quantitatively evaluated in turn.

\subsubsection{Risk investigation and data compilation}

Refer to Table 1 to establish a risk identification checklist during the bridge construction process, search for risk factors during the construction process, and assign a value to each risk factor through the Delphi method. Among them, 25 questionnaires were issued, 15 valid questionnaires were recovered, and the valid data were sorted and input into the IBM SPSS Statistics V21.0 software to perform factor analysis on the data ${ }^{[22]}$, and the output results are shown in Table 2 3.

Table2. Consistency test

\begin{tabular}{cccccc}
\hline $\begin{array}{c}\text { Serial } \\
\text { number }\end{array}$ & Risk factor & Cronbach's alpha $\alpha$ & $\begin{array}{c}\text { Releaseable } \\
\text { variance }(\%)\end{array}$ & $\begin{array}{c}\text { Significant level } \\
\mathrm{p}\end{array}$ & KMO \\
\hline F1 & $\begin{array}{c}\text { Safety factors of } \\
\text { construction personnel } \\
\text { Safety factors of }\end{array}$ & 0.747 & 73.297 & 0.01 & 0.669 \\
F2 & $\begin{array}{c}\text { construction machinery } \\
\text { and materials }\end{array}$ & 0.761 & 52.666 & 0.01 & 0.707 \\
F3 & External environmental & 0.800 & 63.171 & 0.01 & 0.544 \\
\hline
\end{tabular}




\begin{tabular}{|c|c|c|c|c|c|}
\hline & risk factors & & & & \\
\hline F4 & $\begin{array}{c}\text { Risk factors of } \\
\text { improper operation }\end{array}$ & 0.772 & 68.240 & 0.04 & 0.632 \\
\hline F5 & $\begin{array}{c}\text { Influencing factors of } \\
\text { construction } \\
\text { technology }\end{array}$ & 0.804 & 74.148 & 0.00 & 0.661 \\
\hline F6 & $\begin{array}{l}\text { Construction process } \\
\text { management factors }\end{array}$ & 0.894 & 70.623 & 0.00 & 0.690 \\
\hline
\end{tabular}

Table3. The ratio of correlation coefficient and interpretable variance of major construction risk factors of large bridges

\begin{tabular}{|c|c|c|c|c|c|c|c|c|}
\hline $\mathrm{c}$ & Risk factor & $\underset{\text { index }}{\text { Important }}$ & $\begin{array}{c}\text { Variables involved in risk } \\
\text { factors } \\
\text { (risk factor) }\end{array}$ & $\begin{array}{l}\text { Risk } \\
\text { level }\end{array}$ & $\begin{array}{l}\text { Factor } \\
\text { load } \\
\text { value }\end{array}$ & $\begin{array}{l}\text { Project } \\
\text { correlation } \\
\text { coefficient } \\
\text { value }\end{array}$ & $\begin{array}{c}\text { Percentage } \\
\text { of } \\
\text { interpretable } \\
\text { variance } \\
(\%)\end{array}$ & $\begin{array}{l}\text { Cumulative } \\
\text { percentage } \\
(\%)\end{array}$ \\
\hline \multirow{6}{*}{ F1 } & \multirow{6}{*}{$\begin{array}{c}\text { Safety factors } \\
\text { of construction } \\
\text { personnel }\end{array}$} & \multirow{6}{*}{60.92} & People fall factors & 5 & 0.900 & 0.955 & \multirow{6}{*}{15.909} & \multirow{6}{*}{15.909} \\
\hline & & & Mechanical collision and & 4 & 0.864 & 0.857 & & \\
\hline & & & $\begin{array}{l}\text { impact injury } \\
\text { Falling objects }\end{array}$ & 5 & 0.669 & 0.678 & & \\
\hline & & & $\begin{array}{l}\text { Drowning, electric shock } \\
\text { and heatstroke }\end{array}$ & 2 & 0.797 & 0.916 & & \\
\hline & & & Toxic gas leakage factors & 2 & 0.572 & 0470 & & \\
\hline & & & Traffic accident factors & 1 & 0.728 & 0.927 & & \\
\hline \multirow{6}{*}{$\mathrm{F} 2$} & \multirow{6}{*}{$\begin{array}{l}\text { construction } \\
\text { machinery and } \\
\text { materials }\end{array}$} & \multirow{6}{*}{57.77} & Improper maintenance and & 1 & 0.727 & 0.784 & \multirow{6}{*}{13.510} & \multirow{6}{*}{29.419} \\
\hline & & & $\begin{array}{l}\text { Supporting or qualified } \\
\text { factors of construction }\end{array}$ & 2 & 0.525 & 0.787 & & \\
\hline & & & $\begin{array}{l}\text { equipment Equipment } \\
\text { capacity factor Matching }\end{array}$ & 3 & 0.648 & 0.768 & & \\
\hline & & & $\begin{array}{l}\text { or qualification issues } \\
\text { Construction equipment }\end{array}$ & 3 & 0.747 & 0.702 & & \\
\hline & & & $\begin{array}{l}\text { Installation and } \\
\text { commissioning errors }\end{array}$ & 5 & 0.619 & 0.888 & & \\
\hline & & & $\begin{array}{l}\text { Quality factors of raw } \\
\text { materials }\end{array}$ & 5 & 0.646 & 0.754 & & \\
\hline \multirow{4}{*}{ F3 } & \multirow{4}{*}{$\begin{array}{c}\text { External } \\
\text { environmental } \\
\text { risk factors }\end{array}$} & \multirow{4}{*}{68.26} & Complexity of geological & 4 & 0.714 & 0.799 & \multirow{4}{*}{12.756} & \multirow{4}{*}{42.175} \\
\hline & & & conditions & 4 & 0.816 & 0.663 & & \\
\hline & & & Geological factors & 5 & 0.912 & 0.893 & & \\
\hline & & & $\begin{array}{l}\text { Adverse environmental } \\
\text { factors }\end{array}$ & 5 & 0.857 & 0.589 & & \\
\hline \multirow{10}{*}{$\mathrm{F} 4$} & \multirow{10}{*}{$\begin{array}{c}\text { Risk factors of } \\
\text { improper } \\
\text { operation }\end{array}$} & \multirow{10}{*}{69.05} & $\begin{array}{c}\text { Quality factors of } \\
\text { construction personnel }\end{array}$ & 3 & 0.773 & 0.867 & \multirow{10}{*}{11.659} & \multirow{10}{*}{53.834} \\
\hline & & & Personnel protection & & & & & \\
\hline & & & awareness factors & 3 & 0.914 & 0.862 & & \\
\hline & & & Team operation level & & & & & \\
\hline & & & factors & 3 & 0.716 & 0.874 & & \\
\hline & & & Personnel operation & 4 & 0.538 & 0.545 & & \\
\hline & & & factors & 1 & 0.643 & 0.859 & & \\
\hline & & & $\begin{array}{l}\text { Quality factors of } \\
\text { technical personnel }\end{array}$ & 4 & 0.728 & 0.655 & & \\
\hline & & & Effectiveness factors of & & & & & \\
\hline & & & $\begin{array}{l}\text { design content } \\
\text { Delay factors of design } \\
\text { change and approval }\end{array}$ & 4 & 0.788 & 0.784 & & \\
\hline
\end{tabular}

Continued Table 3

\begin{tabular}{|c|c|c|c|c|c|c|c|c|}
\hline $\begin{array}{l}\text { Serial } \\
\text { number }\end{array}$ & Risk factor & $\begin{array}{c}\text { Important } \\
\text { index }\end{array}$ & $\begin{array}{c}\text { Variables involved in risk } \\
\text { factors } \\
\text { (risk factor) }\end{array}$ & $\begin{array}{l}\text { Risk } \\
\text { level }\end{array}$ & $\begin{array}{l}\text { Factor } \\
\text { load } \\
\text { value }\end{array}$ & $\begin{array}{l}\text { Project } \\
\text { correlation } \\
\text { coefficient } \\
\text { value }\end{array}$ & $\begin{array}{l}\text { Percentage } \\
\text { of } \\
\text { interpretable } \\
\text { variance } \\
(\%)\end{array}$ & $\begin{array}{l}\text { Cumulative } \\
\text { percentage } \\
\quad(\%)\end{array}$ \\
\hline \multirow{4}{*}{ F5 } & \multirow{4}{*}{$\begin{array}{l}\text { Influencing } \\
\text { factors of } \\
\text { construction } \\
\text { technology }\end{array}$} & \multirow{4}{*}{54.76} & Inadequate investigation & 2 & 0.86 & 0.862 & \multirow{4}{*}{11.535} & \multirow{4}{*}{65.369} \\
\hline & & & factors Application of new & 5 & 0.883 & 0.839 & & \\
\hline & & & technology and new & & & & & \\
\hline & & & $\begin{array}{c}\text { material } \\
\text { Design and construction }\end{array}$ & 3 & 0.864 & 0.910 & & \\
\hline
\end{tabular}




\begin{tabular}{|c|c|c|c|c|c|c|c|c|}
\hline & & & $\begin{array}{c}\text { factors of temporary } \\
\text { facilities } \\
\text { Construction technology } \\
\text { factors } \\
\text { Rationality of construction } \\
\text { scheme } \\
\text { Accuracy of construction } \\
\text { materials } \\
\end{array}$ & $\begin{array}{l}2 \\
3\end{array}$ & $\begin{array}{l}0.572 \\
0.853 \\
0.644\end{array}$ & $\begin{array}{l}0.478 \\
0.487 \\
0.824\end{array}$ & & \\
\hline F6 & $\begin{array}{l}\text { Construction } \\
\text { process } \\
\text { management } \\
\text { factors }\end{array}$ & 51.70 & $\begin{array}{c}\text { Quality factors of } \\
\text { management personnel } \\
\text { Regulatory management } \\
\text { factors Safety training } \\
\text { factors } \\
\text { On site organization and } \\
\text { management factors } \\
\text { Safety emergency } \\
\text { measures are not perfect }\end{array}$ & $\begin{array}{l}2 \\
3 \\
5\end{array}$ & $\begin{array}{l}0.604 \\
0.736 \\
0.878 \\
0.878\end{array}$ & $\begin{array}{l}0.682 \\
0.707 \\
0.868 \\
0.841\end{array}$ & 11.110 & 76.479 \\
\hline
\end{tabular}

\subsubsection{Data Analysis Process}

\section{(1) Applicability test}

The main purpose of factor analysis is to screen out key risk factors from a large number of risk factors. In order to test the applicability of the factor analysis method, first perform the factor correlation test. The commonly used methods are the KMO measurement method and Bartlett's spherical test method. The larger the KMO measurement value, the higher the applicability. The purpose of Bartlett's spherical test is to determine whether the correlation matrix is the unit matrix usually uses the $\mathrm{P}$ value as the criterion. When the significance level is less than 0.05 , the factor analysis is effective. After testing, the $\mathrm{KMO}$ value is $0.651>0.5$, and the significance level $p$ value is $0.01<0.05$, which verify the requirements. It is appropriate to evaluate the construction risk of large bridges through factor analysis.

(2) Factor extraction

The factor loading matrix reflects the correlation between variables and factors. Use eigenvalue method to extract variables, keep the variable when the eigenvalue of the variable is greater than 1 , and finally get the total amount of specific factors. If the absolute value of the factor load $a_{i j}$ is larger in several rows of $j$ in the column, it means that the factor can explain many variables at the same time, but each variable can only explain a small amount of information. This factor is not representative and can be passed through the factor. The way of rotation changes the representative characteristics so that the factor represents as few variables as possible and has a higher load.

(3) Consistency analysis

Cronbach's Alpha coefficient $\alpha$ is a parameter for judging the consistency of internal risk factors. The size of the parameter represents the degree to which the variable is affected by random errors. $\alpha$ calculation can ensure the reliability of the risk factor value. $\alpha$ must not be less than 0.7 . The larger the value, the test value. The higher the reliability ${ }^{[23]}$, the calculation results show that the cronbach reliability coefficient $\alpha$ of the six main risk factors all meet the requirements.

(4) Construct validity
The Validity is constructed to determine the accuracy of the method. Among the six risk factors, the minimum releasable variance is 0.53 and the maximum is 0.74 . The six factors are single factor factors. The KMO test is used to adapt to each single factor sample. The results show that these factors are acceptable. The standard of aggregate validity is that the explanatory power of the measurement item exceeds its error variance. This article uses the correlation coefficient of the sub-item to the total item to express, and the correlation coefficient of the sub-item to the total item of the variable is greater than 0.4.

(5) Risk factor importance ranking

The higher risk factors can be identified by ranking the importance of risk factors. By controlling them, the incidence of risk accidents can be reduced. The weighted average number of these factors can be summed and then divided by the number of scores. Obtain the importance index of the risk factor.

$$
\begin{aligned}
& A=\sum \frac{a X \times 100}{5} \\
& X=n / N
\end{aligned}
$$

Among them, $A$ is the risk importance index; $a$ is the importance level of the variable; $n$ is the number of survey results in the same level; $N$ is the total number of survey results.

\subsubsection{Analysis of results}

The risk factors of bridge construction process are calculated and analyzed by factor analysis method. The importance of six main risk factors is sorted. The severity of each risk factor is obtained by comparison. Then the risk factors are strictly controlled to reduce the probability of risk events.

The calculation results show that the improper operation of personnel in the process of bridge construction has the most important impact on the construction safety, and its risk importance index is as high as 69.05. Improper construction operation is directly related to the quality and durability of the bridge, which will not only lead to the occurrence of construction accidents, but also lay hidden dangers for the normal work 
of the bridge in the future. Therefore, in the construction process, we should always take the engineering quality as the foundation of engineering construction. meanwhile, In order to establish a quality responsibility system, the construction of key parts and nodes should be strictly in accordance with the operating procedures, and the construction safety should be improved through process control; the external environmental risk importance index is as high as 68.26, and a super large bridge of Zhongkai Motorway is located in Guangdong Province, where there are many uncontrollable factors such as typhoon and flood, so we can contact the local meteorological department to avoid the construction during typhoon peak period do a good job in the protection of the construction site, reduce the impact of Typhoon on the safety of bridge construction, through the statistical analysis of local rainfall data, do a good job of construction protection and reinforcement before the flood season.

In the other four safety factors, the importance index of personnel safety risk factor is 60.92 , the importance index of construction machinery and material safety factor is 57.77 , the importance index of construction technology influencing factor is 54.76 , and the importance index of construction process management factor is 51.70 . These four aspects also have certain influence on the safety risk of bridge construction period. According to different influencing factors, it can be reasonable Take targeted measures for key nodes and parts, so as to reduce the blindness of risk response, save costs, and improve the safety of large bridge construction.

\section{Conclusion}

This paper uses questionnaire survey and expert scoring method and SPSS 21.0 software to carry out factor analysis on the risk factors of bridge construction, and obtain the following conclusions:

(1) Bridge construction risk factors are divided into 6 major risks. In order of importance, they are: personnel misoperation risk, external environment risk, personnel safety risk, construction machinery material safety risk, construction technology risk, and construction process management risk. These risks are the main reason affecting the safety of bridge construction.

(2) According to the specific conditions of the bridge construction project, score and assign 48 risk factors, calculate the scores of the 6 major risks, and then formulate and take corresponding management control measures for the 6 major risks according to the scores.

(3) The method is applied to the construction risk study of a large bridge under construction. Through the score of public factors, the feasibility of this method in the construction risk assessment of large and complex bridges is verified, and the targeted measures are proposed, which provides important basis for the risk control of the subsequent construction of the bridge.

\section{References}

1. Li JX. Risk assessment and management of bridge construction[J]. Transportation World,2018(07):126-

\section{7. (in Chinese)}

2. Zhao S J, Tang X B, Ren W X. (2017) The Statistical Characteristics Analysis of Bridge Accidents and Prevention Principle of Security Risk. Journal of Railway Engineering Society, 34(05):59-64. (in Chinese)

3. Cho T, Kim T S. Probabilistic risk assessment for the construction phases of a bridge construction based on finite element analysis [J]. Steel Construction, 2008, 44(6): 383-400.

4. Azis S. Risk management analysis for construction of Kutai Kartanegara bridge-east Kalimantan-Indonesia [C]// American Institute of Physics Conference Series, 2017: 070003.

5. Haslam R A, Hide S A, Gibb A G F, et al. Contributing factors in construction accidents[J]. Applied Ergonomics, 2005, 36(4): 401-415.

6. Ning X, Qi J, Wu C. A quantitative safety risk assessment model for construction site layout planning [J]. Safety Science, 2018, 104: 246-259.

7. De LT, Eaton D, Betts M, et al. Risk management in the Lusopon te concession - a case study of the two bridges in Lisbon, Portugal [J]. International Journal of Project Management, 2004, 22(1): 63-73.

8. Stewart M G. Reliability-based assessment of ageing bridges using risk ranking and life cycle cost decision analyses [J]. Reliability Engineering \& System Safety, 2001, 74(3): 263-273.

9. Sexsmith R G, Reid S G. Safety factors for bridge false work by risk management [J]. Structural safety, 2003, 25(2): 227-243.

10. Liu QC. Research on safety risk assessment of bridge engineering construction [D]. Shandong University, 2017 (in Chinese)

11. Ouyang XH, Li ZY, Zheng Z, et al. Comprehensive identification and evaluation method of bridge construction risk [J]. Highway engineering, 2013, 38 (5): $30-33$

12. Zhang XD, Guo JF, Yu JY, et al. Risk identification in the construction process of high pier and long span bridge in mountainous area $[\mathrm{J}]$. Beam construction, 2008 (6): $80-83$ (in Chinese)

13. Song CZ. Risk identification of cantilever continuous beam bridge construction process [J]. Zhongwai highway, 2012, 32 (4): 182 - 185 (in Chinese)

14. $\mathrm{Lu} \mathrm{XX,} \mathrm{Xu} \mathrm{XH,} \mathrm{Li} \mathrm{XH,} \mathrm{et} \mathrm{al.} \mathrm{Bridge} \mathrm{construction}$ safety risk assessment based on Kent index method [J]. Chinese Journal of safety science, 2013, 23 (6): 165 - 171 (in Chinese)

15. Lou F, He Y, Liu HQ, et al. Study on overall safety risk assessment method of highway and bridge construction $[\mathrm{J}]$. Chinese Journal of safety science, 2010, 20 (11): 159 - 163 (in Chinese)

16. $\mathrm{Xu} \mathrm{ZS}$, Song $\mathrm{P}$, he $\mathrm{ZJ}$, et al. Assessment of construction schedule risk of super large bridge project by PERT method [J]. Journal of disaster prevention and mitigation engineering, 2009, 29 (1): $83-86$ (in Chinese) 
17. Huang X, Han WW, Chen Fu. Safety assessment and control of highway bridge construction [J]. Highway and automobile transportation, 2013 (6): $210-214$ (in Chinese)

18. Ruan X, Zhu SJ, ye XM. Risk assessment and management of complex bridge construction process [J]. Highway, 2012 (7): 178 - 182 (in Chinese)

19. Yuan B K, Cao C H, Jiang C B, Guo K C, Shang J. (2015) The method for Risk Assessment and Zoning of Sea Ice Disaster based on the Index System of Disaster-inducing Factors. Journal of Institute of Disaster Prevention, 17(02):8-12.(in Chinese)

20. Du D L. (2010) An Analysis of Risk Factors about long-span Continuous Bridges Construction stage. Chang'an University, Xi'an. (in Chinese)

21. Feng D L. (2013) The study on risk assessment and control for tunnel construction safety based on factor analysis-fuzzy analysis. Southwest Jiaotong University, Chongqing. (in Chinese)

22. Li Z X, (2011) Study on Risk Assessment of Longspan Bridges during Construction. Zhengzhou University, Zhengzhou. (in Chinese)

23. Wang S Y, Liu G H, Li F Q, Liu L J. (1998) Integral analysis method and its application to observational data of dam. Journal of Hydraulic Engineering, (05):29-33. (in Chinese) 